US cancer institute shifts funds to external research

Washington. An advisory board to the US National Cancer Institute (NCI) has welcomed a decision by the institute to boost its funding for outside investigators by $\$ 70 \mathrm{mil}-$ lion in the current fiscal year, which began last October. Nearly half of this money is being taken from the institute's existing intramural activities - a move which, not surprisingly, is raising concern among NCI scientists whose projects may be affected.

The new plan is the work of Richard Klausner, the recently-appointed director of $\mathrm{NCI}$, who presented it to members of the National Cancer Advisory Board (NCAB) last week. Describing insufficient research opportunities for outside investigators as "the problem within the core of our enterprise", Klausner promised that he would do "whatever it takes, as long as we actually have the money, to make opportunities available [to such researchers]".

The advisory board does not have the power to veto Klausner's plan. But it raised few questions and did not dissent from the strategy - reflecting the mood at the cancer institute, where the relatively high level of intramural, compared to extramural, spending has recently come under fire.

Last year, for example, a panel of prominent cancer researchers recommended sharp cuts in the level of research funds spent intramurally by the NCI (see Nature 375, 267; 1995). The institute's 1996 budget of $\$ 2.25$ billion makes up almost one-fifth of total spending by the National Institutes of Health (NIH). Of this figure, 19 per cent goes to intramural research, compared to an average of 11 per cent at the NIH's 23 other institutes and centres.

Klausner's plan therefore represents "a tremendous advance", says Barbara Rimer, an oncologist at Duke University Medical School in North Carolina, and chair of the advisory board. "For the first time in years we have the opportunity to advance science in a dramatic way by enabling many more good ideas to get funded."

Klausner has already put in place the mainstay of this plan: an increase in

\section{JET heads for reprieve}

Munich. The European Parliament last week gave its backing to a European Commission proposal to extend the Joint European Torus (JET) nuclear fusion project for an extra three years. Final approval for the extension, which would allow JET to run until the end of 1999, is expected to be given by the European Council of Ministers in the next few weeks. The commission pays 80 per cent of JET's annual budget of around ECU80 million (US\$103 million). the coveted 'RO1' investigator-initiated research grants for basic and clinical research projects by outside scientists. According to Klausner, in the six months since he has become director, 23 per cent of applications for such grants have been funded, compared to only 15 per cent previously. This new level of funding will continue.

Furthermore, in a move that reflects recent calls for more support for clinical researchers, such researchers who fail to rank in the top 23 per cent, but fall within the next 10 per cent, will get an immediate second chance at being funded, provided that they respond promptly to assessments of their proposals. Non-clinical researchers will also be given the same second chance under the new process, called 'accelerated executive review', but only if they fall within the next 4 per cent of applicants.

Klausner calls the current process, in which the amendment and re-submission of applications can often take two years, "a particular problem for patient-oriented research". He told the board that the new, more flexible procedure sends "a very powerful message that we are interested in patient-oriented research". Klausner added that the NCI has set aside sufficient money to fund 40 to 50 per cent of those grant applications that qualify for the immediate second chance.

But the news of additional support for extramural projects has distressed some NCI scientists, who expect to see contract work cut by $\$ 25-\$ 30$ million to help pay for it. "All of us feel a bit like mushrooms kept in the dark and fed you know what," says one laboratory chief at the auxiliary NCI campus at nearby Frederick, Maryland. According to Klausner, about $\$ 10$ million will be cut from contract research at the Frederick campus, whose current budget is about $\$ 150$ million.

"Obviously we're all anxious. We don't know where they're going to find the money," adds another scientist at the campus, the Frederick Cancer Research and Development Center (FCRDC), which provides support services for NCI AIDS and cancer research. The Center's senior manager, Joseph Mayo, says that the cuts will not require lay-offs, but will be absorbed through attrition among the approximately $350 \mathrm{NCI}$ employees and 1,500 contract workers at FCRDC over the next two years.

Klausner claims that much of the new money has been found not by cutting programmes but by improving efficiency. NCI officials say that the remaining $\$ 40-45 \mathrm{mil}-$ lion of the $\$ 70$ million will come from the 5.7 per cent increase that Congress has granted NIH in 1996. Meredith Wadman
International biotech centre opens in Delhi with plea for cash

New Delhi. The final step in establishing the International Centre for Genetic Engineering and Biotechnology (ICGEB) took place in February with the opening of a new building for the centre's laboratories in New Delhi, after occupying temporary accommodation for the past nine years.

The centre's other base at Trieste in Italy moved into new laboratories last year. "With both components now installed in permanent premises, we have concluded the process of setting up the ICGEB," said Ambassador Sergio Cattani, representing the Italian government, at the formal inauguration.

But one major task is still left - ensuring that the centre will be able to attract the financial support that it needs to run its research programmes.

Until now, the two host countries, Italy and India, backed by donations from international agencies, have met the centre's expenses of US\$12 million a year. "Other member countries will have to start paying from 1999," says Arturo Falaschi, the director of ICGEB. "That is the deadline."

Handing over the 10,000-square-metre laboratory complex to ICGEB, Bhubanesh Chaturvedi, India's science minister, said his government had fulfilled its commitment to the international scientific community. While confirming India's continued support, he called upon other member countries to "urgently make their contributions to sustain the centre's excellence". The governments of 35 countries have so far ratified agreements with the ICGEB.

ICGEB, with its structure of twin laboratories, was set up in 1986 by the United Nations Industrial Development Organization (UNIDO) to ensure that developing countries are able to share the benefits of biotechnology. This objective has been achieved, says Falaschi, with about 230 scientists from 28 countries now working at the centre's two laboratories, and $\mathbf{4 0 0}$ more receiving short-term training each year.

Since February 1994, the centre has operated independently of UNIDO. "Now we are really on our own," says Falaschi, adding that "once all the member countries start making contributions, the centre will have no problem on the money front."

According to Falaschi, important contributions from the New Delhi laboratory include a new peptide vaccine for hepatitis $B$, and the isolation of a gene able to impart viral resistance to crops. An inexpensive AIDS diagnostic kit developed at the centre was put on the market in India last month, and will soon be produced locally in Nigeria, Sudan and Morocco.

K. S. Jayaraman 